УДК 351

DOI https://doi.org/10.32849/2663-5313/2020.7.72

\title{
Віта Галушка,
}

канд. наук з держ. упр.,

старший викладач кафедри керівництва війсвками (силами) в мирний час

Національного університету оборони України імені Івана Черняховського

\section{ТЕОРЕТИКО-МЕТОДИЧНІ ЗАСАДИ УПРАВЛІННЯ ПРОЕКТАМИ}

Дослідження, зроблені у статті, зумовлені історією управління проектами, що бере свій початок з виникненням людської иивілізації. Саме проєкти змінюють наш світ. Починаючи зі звичайного для нас повсякденного приготування сніданку й завершуючи глобальним науково-технічним прогресом, представники людства раз за разом проходять одній й ті ж кроки: задумують, планують, упроваджують і контролюють. Але теоретичне оформлення методологічних підвалин проєктної діяльності було зафіксовано тільки в ХХ ст., коли надбанням наукової громадськості стали роботи Гантта, за допомогою діаграм якого можна було легко і зручно в графічній формі відобразити перебіг певних подій з деталізачією за датами й визначити їх тривалість. Американський учений Гулік здійснив першу розробку матричної структури організачії для управління складними проєктами. У практиці управління проєктами і тепер успішно використовуються метод критичного шляху (Critical Path Method - CPM) i метод аналізу й оиінки програм (Program Evaluation and Review Technique - PERT), розробка яких припадала саме на той час. Обидва методи засновані на використанні сітьових діаграм, але метод критичного шляху оперував тільки однією тривалістю роботи, тоді як метод аналізу й оиінки програм ураховував чотири тривалості - оптимістичну, песимістичну, найбільш імовірну й середньозважену. Це зумовлено різними сферами застосування методів. Метод аналізу й оиінки програм був створений для виконання проєкту, навколишнє середовище якого характеризувалася високим ступенем невизначеності, тому доводилося очінювати безліч різних варіантів завершення робіт. Ступінь невизначеності проєктного середовища, в якому вперше використано метод критичного шляху, був істотно меншим, виконавиі могли досить точно оцінити тривалість робіт, грунтуючись на попередньому досвіді проведення подібних робіт у минулому. У середині 50-х років XX ст. теоретичні напрацювання з управління проєктами вперше зазнали серйозної перевірки на практииі завдяки сміливим експериментам з упровадження новітніх наукових розробок у сферу управління надсекретним виробництвом військовими відомствами Сполучених Штатів Америки Офісами спільних проєктів Військово-повітряних і Військово-морських сил США, а також Офісом спечіальних проєктів з озброєння. В основу інструментарію управління військовими проєктами з озброєння було покладено сітьове планування, основними перевагами якого є формалізачія алгоритму розрахунку, що враховує технологію реалізацї проєкту, $і$ можливість виявити перелік робіт, що визначають тривалість проєкту. Свогодні «Основи знань з проєктного менеджменту» у своїй черговій редакиій являють собою найбільш повну збірку професійних знань у сфері управління проєктами, включаючи традииійні методи, що вже позитивно зарекомендували себе, i нові, що мали лище обмежене застосування.

Ключові слова: поняття проєкту, управління проєктами, учасники проєкту, формування команди проєкту, стандарти, система знань.

Постановка проблеми. Період 90 -х років ХХ ст. відзначений подальшою систематизацією досвіду й теоретичним узагальненням уже наявних знань. Усвідомлюються можливості застосування управління проєктами в нетрадиційних сферах, таких як соціальні, економічні, великі міжнародні проєкти, вивчаються можливості використання засобів і методів управління відповідно до вимог проведення структурних реформ. Розробляються й уводяться в дію національні й міжнародні програми сертифікації менеджерів проєкту й одночасно розпочинаються процеси уні- фікації та стандартизації у сфері управління проєктами. Окрім цього, з 1990 р. інструментарій проєктного менеджменту поповнюється імітаційним моделюванням, а з 1995 р. - філософією управління проєктом.

Аналіз останніх досліджень і публікацій. Розвиток наукового апарату управління проєктами в останні десятиліття відбувається дуже високими темпами. Теоретичне, методологічне та практичне обгрунтування висвітлено у дослідженнях багатьох учених, як зарубіжних, так і вітчизняних. Це, зокрема, О. В. Бірюков, Т. Г. Фесенко, I. В. Тріфонов, 
Н. Ю. Калініна, О. І. Шипуліна, С. В. Антоненко, А. С. Товб, Г. Дитхелм, Е. Tsang, H. Karzner. Сфера застосування знань проєктного менеджменту щорічно опиняється у вирі настільки грандіозних подій, що кожні два-три роки історію управління проєктами необхідно переписувати практично заново.

Мета статті. Відповідно, метою статті $€$ обгрунтування теоретико-методологічних засад та розроблення науково-практичних рекомендацій щодо управління проектами. Досягнення поставленої мети зумовлює вирішення низки таких завдань:

- дослідження думок науковців про змістову сутність засад управління проєктами;

- формування визначення поняття проєкту та управління проєктами;

- обгрунтування концептуальних „ напрямів теорії проєктного управління.

Виклад основного матеріалу. Термін «проєкт» (від латинського - «кинутий вперед») трактується як креслення, пояснювальна записка і кошториси, на основі яких будуються основні виробничі фонди; або це текст, що передує документу - плану, договору, угоді. Наведемо ще кілька варіантів визначення поняття «проєкт», які зустрічаються в літературі.

Проєкт - це окреме підприємство 3 конкретними цілями, які часто включають вимоги до часу, вартості та якості результатів, а також визначеними вихідними даними, що обумовлюють спосіб їх вирішення [5].

Проєкт - це певне завдання з визначеними вихідними даними й встановленими результатами (цілями), що обумовлюють спосіб його вирішення [3, с. 132].

У різних дослідженнях можна зустріти й інші визначення поняття «проєкт», проте всі вони включають ознаки, загальні для всіх проєктів:

- чіткі цілі, які досягаються одночасним виконанням сукупності технічних, економічних, фінансових, організаційних та інших вимог;

- внутрішні і зовнішні взаємозв'язки операцій, задач і ресурсів, які вимагають координації в процесі виконання проєкту;

- чітко визначені терміни початку і закінчення проекту;

- обмежені ресурси;

- унікальність умов реалізації;

- неминучість різного роду конфліктів.

I. Мазур, В. Шапіро, Н. Ольдерогге виділяють такі елементи проєкту:

- задум (проблема, завдання);

- засоби реалізації (рішення);

- цілі реалізації (результати, рішення).
На підставі аналізу праць науковців та дослідників даного питання серед основних особливостей, обов'язкових характеристик, які притаманні будь-якому проєкту, ми вважаємо, можна визначити такі:

по-перше, кожен проєкт має завдання, мету, що виражаються в певному кінцевому результаті;

по-друге, кожен проєкт має дати початку та кінця, проміжні дати отримання або досягнення певних проміжних результатів;

по-третє, кожен проєкт потребує різноманітних ресурсів - фінансових, кадрових, технічних, технологічних тощо, які інколи бувають вкрай обмеженими, мають певний ліміт.

При цьому не кожна діяльність або справа можуть бути проєктом. П. Мартін та К. Тейт у праці «Управління проєктами» виділяють поняття «проєкт» та «бізнес-процес», які мають суттєві концептуальні відмінності [4, с. 18]. Водночас будь-який проєкт може стати початком бізнес-процесу, певного виробничого циклу або процесу. Так, зазначені автори стверджують, що проєкт є тимчасовим процесом, який має початок та кінець, а бізнес-процес - це безперервний процес, протягом якого повторяються одні й ті ж дії; результат проєкту є унікальним і він є однократною дією, а результат бізнес-процесу однаковий кожен раз при виконанні поставлених завдань, і він має циклічний характер. Враховуючи вищевикладене, можна зазначити, що кінцевою метою, основним завданням будь-якого проєкту є унікальний продукт, послуга.

Поняття проєкту в різних дослідженнях, моделях та стандартах може трактуватись 3 урахуванням різних аспектів, позицій. У широкому сенсі проєктом можна вважати будь-яку діяльність, яка призводить до певних змін. Окремі автори (П. Мартин, К. Тейт) зазначають, що поняття проєкту може мінятися залежно від визначених завдань, запланованих результатів, секторів економіки тощо. Аналізуючи найбільш поширені визначення поняття «проєкт», можна виділити такі основні критерії, які покладені в їх основу: проєкт як певний тривалий процес; процес як сукупність певних дій; проєкт як певний вид діяльності; проєкт як певне підприємство.

Управління проєктами, за визначеннями I. I. Мазура і В. Д. Шапіро, трактується як вид професійної діяльності, що включає планування, організацію, моніторинг та контроль усіх аспектів проєкту для реалізації його цілей. Крім того, поняття «управління проєктами» не має однакового тлумачення в країнах - засновниках проєктного управління: 
- управління проєктом (УП) або (від англ. - project management) - мистецтво керівництва і координації людських і матеріальних ресурсів протягом життєвого циклу проєкту шляхом застосування сучасних методів і техніки управління для досягнення певних результатів у проєкті за складом та обсягом робіт, вартістю, часом, якістю і задоволенням учасників проєкту [2, с. 350$]$;

- управління проєктами відповідно до міжнародного стандарту ISO 21500: 2012 застосування методів, інструментів, технік і компетенцій до проєкту [1];

- Х. Танака і С. Д. Бушуєв визначають управління проєктами, відповідно до Р2М, як поєднання науки і мистецтва, які використовуються в професійних сферах проєкту, щоб створити продукт проєкту, який би задовольнив місію проєкту, шляхом організації надійної команди проєкту, ефективно поєднує технічні та управлінські методи, створює найбільшу цінність і демонструє ефективні результати роботи [6, с. 46].

Сьогодні існує велика кількість стандартів управління проєктами. Серед сучасних стандартів PMI (Project Management Institute - Інститут управління проектами), зазначених на офіційному сайті Інституту, $€$ такі групи: основні стандарти, практичні стандарти та структури та додаткові стандарти. До першої групи віднесені: $\mathrm{PMBoK}$, OPM3, The Standart for Project Management, The Standart for Portfolio Management.

До другої - Practice Standart for Project Risk Management, Practice Standart for Earned Value Management, Practice Standart for Project Configuration Management, Practice Standart for Work Breakdown Structures, Practice Standart for Scedulung, Practice Standart for Project Estimating, Project Manager Competency Development Framework

До третьої - Construction Extention to the PMBOK Guide, Government Extention to the PMBOK Guide. Але це не всі стандарти, які сьогодні діють.

Географія поширення стандартів приблизно така: PMBoK найбільш поширений в CША, Pociї, PRINCE 2 - у Великобританії, P2M - в Японії. Також існує безліч національних стандартів інших розвинених країн. Серед стандартів з розширеною географією застосування - IPMA (основне розповсюдження - Свропейський Союз), MSA EN 9200:2004 (Свропа), ISO 10006:2003 i GAPPS (міжнародні стандарти) [6].

Для кращого розуміння смислового наповнення міжнародних стандартів управління проєктами розглянемо найбільш поширені серед них.
Зібрання знань з управління проєктами PMBoK 1996 (A Guide to the Project Management Body of Knowledge) - стандарт, розроблений Інститутом проєктного менеджменту (PMI) у 1996 році. Стандарт базується на процесному підході. Повністю визначені взаємодії між усіма процесами, які включені у сфери знань управління проєктами. PMBоK, є єдиним стандартом у галузі проєктного менеджменту, який відповідає ISO 9001.

Управління націлене на забезпечення заданого рівня якості проєкту як на рівні процесів, так і на рівні продуктів. Великою мірою за змістом спирається на РМBOK 1996, має місце збіг аж до назв сфер знань управління проєктами.

Система знань про процеси управління проектами Prince 2 (Projects in Controlled Environments - проєкти у контрольованих умовах) - це методологія управління проєктами, розроблена агентством ССТА (Central Computer and Telecommunications Agency) в 1989 р. як урядовий стандарт Великобританії для управління проєктами в інформаційних технологіях. Методологія Prince 2 є процесно орієнтованою 3 фокусом на продукт (product-based). Prince 2 являє собою метод управління проєктами в рамках чітко визначеної структури організації. Prince 2 описує процедури координації людей та дій в проєкті, як розробляти та контролювати проєкт та що робити, якщо необхідно внести зміни до проєкту у зв'язку 3 відхиленням від плану впровадження. Розподілення на етапи, якими можливо управляти, забезпечує ефективний контроль ресурсів.

Наступний поширений стандарт - P2M (скорочення від Project and Program Management for Enterprise Innovation - проєктний та програмний менеджмент для інновацій підприємства) - це розроблена в Японії новаторська рамкова методологія управління програмами і проєктами в рамках організації 3 використанням інноваційних технологій на рівні підприємств у нестабільному середовищі.

Відмінність цієї методології полягає в орієнтованості не на продукт, а на покращання організації у результаті виконання проєктів.

Рамкова методологія Р2M базується на «трилемі»: складність, цінність та опір (Complexity, Value and Resistance), що становлять так званий «залізний» трикутник контекстних обмежень, в рамках яких здійснюється інноваційна діяльність.

В управлінні проєктами виділяють кілька ключових етапів функціонування команди 
проекту: формування, створення, розвиток, трансформація і розформування.

Сьогодні відсутні наукові роботи з проблем управління проєктами, у яких би не розглядалося питання вибору керівника проєкту, формування команд проєктів, процес управління людськими ресурсами й інших компонентів, які трактуються як «м'які». Це пояснюється тим, що, за результатами опитування центру досліджень управління проєктами Манчестерського університету науки і технологій (UMIST), одними з визначальних чинників успішної діяльності компаній $84 \%$ опитаних вважають членів команди проекту і $100 \%$ - лідера. У наведених результатах досліджень CHAOS, які проводились компанією The Standish Group, і було визначено, що третім за пріоритетним із десяти найбільш важливих чинників, що визначають успіх проєкту, є робота в проєкті досвідченого менеджера. За результатами аналізу досвіду нереалізованих проєктів були визначені причини їх невиконання, більшість із яких безпосередньо пов'язані 3 «м'якими» компонентами. Таким чином, за моделлю оцінки проєктів «Project Excellence» з 500 балів, що виділяються на оцінку «майстерності» управління проєктами, 150 описують якість управління людськими ресурсами, що підкреслює важливість даного напряму [4].

\section{Висновки}

Останніми роками з'явилося досить літератури, яка присвячена питанням управління проєктами. В основному це перекладені російською мовою роботи зарубіжних авторів, але є і вітчизняні. Велика частина видань містить теоретико-методологічні засади управління проєктами, при цьому деякі з них вже не відповідають вимогам сучасних проєктів. Іншу частину методів, особливо з публікацій зарубіжних авторів, без додаткової адаптації не можна використовувати за призначенням через специфіку національних особливостей в управлінні проєктами та менталітет вітчизняних проєктних менеджерів. Нерозуміння цього веде до неправильного застосування відповідних методик, отримання помилкових результатів, прийняття на їх підставі рішень, які призводять до невиконання проєкту. Тому більшість дослідників схиляються до думки, що головна причина невиконання проєктів полягає не стільки в недотриманні технології виробництва, скільки в некомпетентності команди проєкту.

\section{Список використаних джерел:}

1. Иванов В. І. Комментарии к международному стандарту ISO 21500:2012. Київ, 2012. 375 с.

2. Управление проектами / И.И. Мазур, В.Д. Шапиро, И.Г. Ольдерогге ; за ред. И.И. Мазур. Москва : Экономика, 2001. 574 с.

3. Марунич В.С. Щодо системності факторів уніфікації проекту побудови пасажирських маршрутних систем міст. Ринок послуг комплексних транспортних систем та прикладні проблеми логістики : праці XII міжнар. наук.-практ. конф., 11 травня 2011 р. Київ : МТЗУ, 2011. С. 131-133.

4. Мартин П., Тейт К. Управление проектами / пер. с англ. В.Б. Боброва. Москва, 2006. $224 \mathrm{c}$.

5. Полковников А.В. Модель "Project Excellence" - в поисках совершенства. 2016. С. 30-36. URL: http//www.pmpractice.ru/knowledgebase/ publications $/$ ?id=242\&detail (дата звернення: 01.07.2020).

6. Стандарти управління проектами: клуб проектних менеджерів. Клуб проектних менеджеpiв pm-Club : веб-сайт URL: http://info.pm-club.org/ standarty (дата звернення: 02.07.2020).

7. Руководство к Своду знаний по управлению проектами. США : Project Management Institute Inc. Pennsylvania, 2013. 614 c. (Руководство РМВОК®).

8. Ярошенко Ф.А., Бушуев С.Д., Танака Х. Управление инновационными проектами и программами на основе системы знаний Р2М. Київ, 2011. $268 \mathrm{c}$

\section{Vita Halushka. Theoretical and methodological principles of project management}

The research is done in the article, due to the history of project management dates back to the emergence of human civilization. It is projects that change our world. From our usual daily breakfast to global scientific and technological progress, humanity has repeatedly taken the same steps: planning, planning, implementing and monitoring. But the theoretical design of the methodological foundations of project activities was recorded only in the twentieth century. The American scientist Gulik made the first development of the matrix structure of the organization for managing complex projects. The Critical Path Method (CPM) and the Program Evaluation and Review Technique (PERT), which were developed at the time, are still used successfully in project management practice. Both methods are based on the use of network diagrams, but the critical path method operated with only one duration, while the method of analysis and evaluation of programs took into account four durations - design environment, in which the critical path method was used for the first time, was significantly lower, the executors were able to estimate the duration of work quite accurately, based on previous experience of similar work in the past. During the 50-s the XX century, theoretical developments in project management for the first time underwent serious testing in practice due to bold experiments to 
implement the latest scientific developments in the field of management of oversect production by US military agencies. The toolkit for the management of military armament projects was based on network planning, the formalization of the calculation algorithm that takes into account the technology of project implementation, and the ability to identify a list of works that determine the duration of the project/ Today, the Project Management Knowledge Base, in its next version, is the most complete collection of professional knowledge in the field of project management, including traditional methods that have already proven themselves and new ones that have only limited application.

Key words: project concept, project management, project participants, project team formation, standards, knowledge system. 